\title{
Cellulosic industrial waste to enhance Pinus taeda nutrition and growth: a study in subtropical Brazil
}

\author{
Resíduo industrial celulósico para melhorar o crescimento e a nutrição do \\ Pinus taeda: um estudo no Brasil subtropical
}

\author{
Anne Luize Sass ${ }^{1}$, Marcos Vinícius Martins Bassaco ${ }^{2}$ (D), Antonio Carlos Vargas Motta ${ }^{1}$ (D), \\ Shizuo Maeda ${ }^{3}$, Julierme Zimmer Barbosa ${ }^{4}$ (1), Itamar Antonio Bognola ${ }^{3}$ (1), \\ João Vasconcellos Gomes Bosco ${ }^{3}$ (D), Gabriel Democh Goularte ${ }^{1}$ (D), Stephen Arthur Prior ${ }^{5}$ (D) \\ ${ }^{1}$ Universidade Federal do Paraná - UFPR, Curitiba, PR, Brasil \\ ${ }^{2}$ Faculdade de Jaguariaíva - FAJAR, Jaguariaíva, PR, Brasil \\ ${ }^{3}$ Empresa Brasileira de Pesquisa Agropecuária - EMBRAPA Floresta, Colombo, PR, Brasil \\ ${ }^{4}$ Instituto Federal do Sudoeste de Minas Gerais - IF do Sudoeste de Minas Gerais, Barbacena, MG, Brasil \\ ${ }^{5}$ United States Department of Agriculture - USDA-ARS, Auburn, AL, United States
}

Como citar: Sass, A. L., Bassaco, M. V. M., Motta, A. C. V., Maeda, S., Barbosa, J. Z., Bognola, I. A., Bosco, J. V. G., Goularte, G. D., Prior, S. (2020). Cellulosic industrial waste to enhance Pinus taeda nutrition and growth: a study in subtropical Brazil. Scientia Forestalis, 48(126), e3165. https://doi.org/10.18671/scifor.v48n126.13

\begin{abstract}
The objectives of this work were to evaluate the influence of a compost (cellulosic sludge - 70\%, boiler ash - 30\%) on the development of Pinus taeda trees on low-growth sites in subtropical Brazil that displayed symptoms of deficiency in previous cycles, and to evaluate how the compost influences soil chemical characteristics. Six months after seedling transplant, five rates (control, 14, 25, 49 and $60 \mathrm{Mg} \mathrm{ha}^{-1}$ ) of compost were manually broadcast. For the following three years, soil and needle samples were collected for nutrient analysis along with plant growth measurements. Soil analysis indicated small increase in $\mathrm{K}$ availability and decrease in exchangeable Al. Large growth enhancements were observed in terms of plant height and diameter at breast height, and needle chlorosis disappeared when compost was applied. After three years of compost application, trunk volume increased from $13 \mathrm{~m}^{3} \mathrm{ha}^{-1}$ in the control to $37 \mathrm{~m}^{3} \mathrm{ha}^{-1}$ in the $49 \mathrm{Mg} \mathrm{ha}^{-1}$ treatment. $P$. taeda growth was inversely related to $\mathrm{Mn}$ and directly related to $\mathrm{K}$ and $\mathrm{B}$ foliar concentration. Findings suggest that compost application should be encouraged since it enhances initial growth of $P$. taeda, being an important way to recycle residue from the paper industry and contribute to more sustainable management of low fertility soils.
\end{abstract}

Keywords: Organic fertilization; Sandy soil; Reforestation production; Nutritional balance; Manganese accumulation.

\section{Resumo}

Os objetivos deste trabalho foram avaliar a influência de um composto (70\% de lodo e 30\% de cinza de caldeira) no desenvolvimento de árvores de Pinus taeda em locais de baixo crescimento no Brasil subtropical que apresentavam sintomas de deficiência em ciclos anteriores, e avaliar como o composto influencia as características químicas do solo. Seis meses após o transplante das mudas, foram aplicadas manualmente cinco doses do composto (controle, 14, 25, 49 e $60 \mathrm{Mg} \mathrm{ha}^{-1}$ ). Nos três anos seguintes, amostras de solo e acículas foram coletadas para análise de nutrientes, juntamente com as medidas dendrométricas das plantas. A análise do solo indicou pequeno aumento na disponibilidade de $\mathrm{K} e$ diminuição do Al trocável. Grandes melhorias no crescimento foram observadas em termos de altura e diâmetro na altura do peito, e a clorose da acícula desapareceu quando o composto foi aplicado. Após três anos de aplicação do composto, o volume de tronco aumentou de $13 \mathrm{~m}^{3} \mathrm{ha}^{-1}$ do controle para $37 \mathrm{~m}^{3}$ ha-1 no

Financial support: The authors thank the Iguaçu Celulose e Papel companies and Embrapa Floresta for field work support. The authors thank the National Council for Scientific and Technological Development (CNPq) for financial support (project n 308383/2012-5) and to the Coordination for the Improvement of Higher Education Personnel (CAPES) for scholarship support.

Conflict of interest: Nothing to declare.

Corresponding author: marcos.bassaco@hotmail.com

Received: 17 October 2018.

Accepted: 10 July 2019.

Editor: Francides Gomes da Silva Júnior

(c) (i) This is an Open Access article distributed under the terms of the Creative Commons Attribution License, which permits unrestricted use,

c) distribution, and reproduction in any medium, provided the original work is properly cited. 
tratamento com $49 \mathrm{Mg} \mathrm{ha}^{-1}$. O crescimento de $P$. taeda foi inversamente relacionado ao Mn e diretamente relacionado à concentração foliar de $\mathrm{K}$ e $\mathrm{B}$. Os resultados sugerem que a aplicação de composto deve ser realizada, uma vez que aumenta o crescimento inicial de $P$. taeda, sendo uma maneira importante de utilizar resíduos da indústria de polpa celulósica e contribuir para um manejo mais sustentável de solos de baixa fertilidade.

Palavras-chave: Adubação orgânica; Solo arenoso; Produção de reflorestamento; Equilíbrio nutricional; Acumulação de manganês.

\section{INTRODUCTION}

Due to a global demand for reforested wood, $\sim 37$ million hectares have been planted with the genus Pinus (Del Lungo et al., 2006; Morland et al., 2018). In Brazil, this area occupies 1.6 million hectares (Instituto Brasileiro de Árvores, 2017), mainly concentrated in the southern region of the country, and comprises $88 \%$ of all plantations (Associação Brasileira de Produtores de Florestas Plantadas, 2013). Pinus taeda L. exhibits excellent adaptation to the soils and climatic conditions of subtropical Brazil and is currently the most planted conifer species (Motta et al., 2014; Moro et al., 2014). This adaptability is evidenced by a high Brazilian productivity $\left(31 \mathrm{~m}^{3} \mathrm{ha}^{-1} \mathrm{yr}^{-1}\right)$, which is among the best for planted-conifer forests in the world (Instituto Brasileiro de Árvores, 2017).

Forest species in subtropical Brazil are usually planted on poor soils. In general, these soils are characterized by very low nutrient availability and high acidity (Rabel et al., 2018; Reissmann \& Wisniewski, 2005). In addition, fertilizer and lime amendments for improved nutrient availability or to return nutrients lost from logging are not common practices (Motta et al., 2014). This is an important consideration given that high Pinus productivity can lead to soil nutrient exhaustion in just a few logging cycles. Some researchers have reported nutrient deficiency symptoms (Reissmann \& Wisniewski, 2005; Chaves \& Corrêa, 2005) that suggest a need for intervention with fertilizer and/or lime applications.

Pulp wood processing of pine generates multiple residue streams (e.g., wood bark, lime mud, cellulosic sludge, and boiler ash), and each produced $\mathrm{Mg}$ of cellulose generates $\sim 0.15 \mathrm{Mg}$ of waste (Nolasco et al., 2005). Given the expansion of paper and cellulose production in Brazil (Associação Brasileira de Produtores de Florestas Plantadas, 2013), landfill accumulation of this waste can be expensive and may raise environmental concerns. Thus, utilizing this waste as a nutrient source for low-fertility forest plantations is a potential alternative disposal method that may be more environmentally friendly than landfilling.

Pulp industry waste (e.g., ash and lime mud) has a high concentration of elements important to plant growth such as $\mathrm{K}, \mathrm{Ca}, \mathrm{Mg}$, and $\mathrm{P}$ (Ortega Rodriguez et al., 2018; Dibdiakova et al., 2015; Mandre et al., 2006); use of these wastes on low fertility soils could decrease soil acidity while increasing the availability of one or more nutrients (Mandre et al., 2006). Forest growth response to residue application has been variable, ranging from large increases (Ortega Rodriguez et al., 2018; Sikstrom et al., 2010; Rodrigues et al., 2005) to no change (Mandre et al., 2006; Parn, 2005) or reduced growth (Parn, 2005; Jacobson, 2003). Lack of a clear growth response to pulp residues is likely due to variation in nutrient concentration inherent to these materials and application rate. According to Motta et al. (2014), the presence of several nutrients in pulp industry residues results in higher growth rates than fertilizer use, which may be related not only to nutrient supply, but to other beneficial effects of organic wastes, such as water retention and increased biological activity.

Similar to growth response, changes in tree nutritional status resulting from residue application can be variable. Of thirteen elements evaluated after 26 years of residue application, Sikstrom et al. (2010) found increased K, P, and Mn and decreased N concentration in needle tissue. However, Varnagiryte-Kabašinskiene et al. (2015) reported no variation in needle $\mathrm{N}, \mathrm{P}, \mathrm{K}, \mathrm{Ca}$, and $\mathrm{Mg}$ concentrations when ash was applied. While evaluating Pinus taeda under subtropical conditions, Rodrigues et al. (2005) observed decreased $\mathrm{N}$ and $\mathrm{P}$ and increased $\mathrm{K}, \mathrm{Mg}$, and $\mathrm{Ca}$ after 7 years of applying forest industry residue. 
Clearly, more work is required to understand how tree growth is impacted by different forest industry residues applied to plantation soils. The objectives of this work were to evaluate the influence of a compost (cellulosic sludge and boiler ash mixture) on the development of Pinus taeda trees on low-growth sites that displayed symptoms of deficiency in previous cycles, and to evaluate how the compost influences soil chemical characteristics.

\section{MATERIAL AND METHODS}

\section{Study area characteristics}

The experiment was established in Piraí do Sul municipality, state of Paraná, Brazil ( $24^{\circ} 24$ '27.36"S and 49 $58^{\prime} 34.70^{\prime \prime} \mathrm{W}$, altitude of $1102 \mathrm{~m}$ ). Subtropical grassland was the native vegetative state of the study site. According to Köeppen climate classification, the climate of the region is $\mathrm{Cfb}$ (C - Humic Subtropical Zone; $\mathrm{f}$ - Oceanic Climate, without dry season; $b$ - with temperate summer), with annual temperatures varying between 16 and $18^{\circ} \mathrm{C}$ (Alvares et al., 2013) and average annual rainfall of 1400 to $1600 \mathrm{~mm}$ (Table 1).

Table 1. Average monthly precipitation (mm) from 2011 to 2014 at Piraí do Sul, Paraná State, Brazil.

\begin{tabular}{cccccccccccccc}
\hline Year & Jan & Feb & Mar & Apr & May & Jun & Jul & Aug & Sep & Oct & Nov & Dec & Total \\
\hline 2011 & 265 & 147 & 129 & 92 & 8 & 86 & 125 & 180 & 17 & 193 & 140 & 71 & 1453 \\
2012 & 217 & 148 & 57 & 224 & 57 & 301 & 83 & 7 & 73 & 62 & 149 & 119 & 1497 \\
2013 & 126 & 267 & 130 & 75 & 123 & 282 & 132 & 11 & 145 & 118 & 68 & 119 & 1596 \\
2014 & 208 & 45 & 125 & 132 & 84 & 144 & 62 & $40 *$ & & & & & 840 \\
\hline
\end{tabular}

*August 2014: last month of data collection.

The soil of the region has sandstone source material and the relief is undulating. This area had previously been cultivated with $P$. taeda (i.e., two 12-year cycles) and remaining residues were not burned after tree harvests. Records from this experimental area indicated that no fertilizer or lime had been applied, and the site displayed low growth rates and chlorotic symptoms of nutritional deficiency. The soil of the experiment area was classified as typic Orthic Quartzarenic Neosol from an open profile. Soil samples were collected from the $0-20 \mathrm{~cm}$ soil layer prior to experiment establishment and analyzed following the methodology of Silva (1999). The following results were obtained: $3.67 \mathrm{~g} \mathrm{dm}^{-3}$ of organic $\mathrm{C}, 4.07$ of $\mathrm{pH}-\mathrm{CaCl}_{2}-0.01 \mathrm{M} ; 0.2 \mathrm{mg} \mathrm{dm}^{-3}$ of P - Mehlich-1; $3.97 \mathrm{cmol}_{\mathrm{c} \mathrm{dm}} \mathrm{dm}^{-3}$ of $(\mathrm{H}+\mathrm{Al}) ; 0.04 \mathrm{cmol}_{\mathrm{c}} \mathrm{dm}^{-3}$ of $\mathrm{Ca}^{++} ; 0.02 \mathrm{cmol}_{\mathrm{c}} \mathrm{dm}^{-3} \mathrm{of} \mathrm{Mg}^{++}$; $0.03 \mathrm{cmol}_{\mathrm{C}} \mathrm{dm}^{-3}$ of K $; 0.69 \mathrm{cmol}_{\mathrm{C}} \mathrm{dm}^{-3}$ of Al $\mathrm{Al}^{+3}$; and $138 \mathrm{~g} \mathrm{~kg}^{-1}$ of clay and $788 \mathrm{~g} \mathrm{~kg}^{-1}$ of sand.

\section{Treatments and experimental design}

The imposed treatments consisted of increasing rates of a compost residue generated by the cellulose industry cultivating the area used for the experiment. Residue rates were selected to increase the soil base saturation by $20,40,60$, and $80 \%$, which corresponds to $14,25,49$, and $60 \mathrm{Mg} \mathrm{ha}^{-1}$ of dry material, respectively. In addition, a control receiving no compost application was included. The experiment was implemented as a randomized block design with five replications ( 25 plots).

\section{Compost residue characterization}

The residue utilized was a mixture of $70 \%$ cellulosic sludge and $30 \%$ boiler ash that was composted for $\sim 12$ months in the open air. A sample of the compost residue was collected from the compost pile and sent to a laboratory for chemical characterization using the methodology described by Brasil (2014); results are shown in Table 2, as well as tested rates and their respective nutritional concentrations. 
Table 2. Content of $\mathrm{N}, \mathrm{P}_{2} \mathrm{O}_{5}, \mathrm{~K}_{2} \mathrm{O}, \mathrm{MgO}, \mathrm{CaO}, \mathrm{S}, \mathrm{Fe}, \mathrm{Cu}, \mathrm{B}, \mathrm{Mn}, \mathrm{Zn}$, and organic matter (OM) in the compost (70\% cellulosic sludge and $30 \%$ boiler ash) and equivalence of each nutrient applied per treatment at Piraí do Sul, Paraná State, Brazil.

\begin{tabular}{|c|c|c|c|c|c|}
\hline & & \multicolumn{4}{|c|}{ Treatment (Mg ha-1) } \\
\hline & Sludge + Ash & 14 & 25 & 49 & 60 \\
\hline & $\mathrm{g} \mathrm{kg}^{-1}$ & \multicolumn{4}{|c|}{ kg ha-1 } \\
\hline $\mathrm{N}$ & 8.9 & 124 & 222 & 436 & 534 \\
\hline $\mathrm{P}_{2} \mathrm{O}_{5}$ & 3.6 & 50 & 90 & 176 & 216 \\
\hline $\mathrm{K}_{2} \mathrm{O}$ & 4.5 & 63 & 112 & 220 & 270 \\
\hline $\mathrm{MgO}$ & 7.7 & 107 & 192 & 377 & 462 \\
\hline $\mathrm{CaO}$ & 7.1 & 99 & 177 & 347 & 426 \\
\hline $\mathrm{S}$ & 8.1 & 113 & 202 & 396 & 486 \\
\hline \multirow[t]{2}{*}{$\mathrm{OM}$} & 560 & 7,840 & 14,000 & 27,440 & 33,600 \\
\hline & $\mathrm{mg} \mathrm{kg}^{-1}$ & \multicolumn{4}{|c|}{$\mathrm{kg} \mathrm{ha}^{-1}$} \\
\hline $\mathrm{Fe}$ & 7800.0 & 109 & 195 & 382 & 468 \\
\hline $\mathrm{Cu}$ & 13.0 & 0.2 & 0.3 & 0.6 & 0.8 \\
\hline B & 181.8 & 2.5 & 4.5 & 8.9 & 10.9 \\
\hline $\mathrm{Mn}$ & 537.6 & 7.5 & 13.4 & 26.3 & 32.3 \\
\hline $\mathrm{Zn}$ & 94.6 & 1.3 & 2.4 & 4.6 & 5.7 \\
\hline
\end{tabular}

\section{Experiment establishment and evaluation}

P. taeda seedlings were planted in January 2011 at a spacing of $2.5 \mathrm{~m} \times 2.5 \mathrm{~m}$. In June of the same year, the blocks and experimental plots were laid out; each plot consisted of five lines with five plants per line for a total of 25 trees. The nine central trees were considered as useful for sampling. Immediately after plot demarcation, the compost residue (cellulosic sludge and boiler ash mixture) was manually broadcasted on the soil surface without incorporation. To achieve the appropriate treatment rates, compost moisture was taken into account when weighing the material.

At the end of August (2011, 2012, 2013, and 2014), soil samples were collected with a Dutch auger from the $0-10$ and $10-20 \mathrm{~cm}$ layers such that a total of six simple samples for both depths were collected from each plot. The soil samples were dried in a forced air oven $\left(60^{\circ} \mathrm{C}\right)$ and ground to pass through a $2 \mathrm{~mm}$ sieve. These dry ground samples were analyzed for $\mathrm{pH}(0.01 \mathrm{M} \mathrm{CaCl}$; $1: 5$ soil:solution), $\mathrm{Al}, \mathrm{Ca}, \mathrm{Mg}, \mathrm{K}, \mathrm{P}, \mathrm{Zn}, \mathrm{Mn}, \mathrm{Fe}, \mathrm{Cu}$, and $\mathrm{C}$ according to procedures of Silva (1999). For $\mathrm{Al}, \mathrm{Ca}$, and $\mathrm{Mg}$ extractions, $1 \mathrm{MKCl}$ was used. For $\mathrm{K}, \mathrm{P}$, and micronutrients, Mehlich $1\left(0.05 \mathrm{MHCl}\right.$ and $\left.0.0125 \mathrm{M} \mathrm{H}_{2} \mathrm{SO}_{4}\right)$ was used. For $\mathrm{C}$ determination, each vial representing one sample received sodium dichromate $\left(\mathrm{Na}_{2} \mathrm{Cr}_{2} \mathrm{O}_{7}\right)+\mathrm{H}_{2} \mathrm{SO}_{4}$.

Biometric tree evaluations were also conducted in 2012, 2013, and 2014. Height (h) of the nine central trees in each plot was measured using a graduated extendable aluminum ruler measuring five meters. Diameter at breast height $(\mathrm{DBH}=1.3 \mathrm{~m})$ of the nine trees per plot were measured with a digital caliper. After these initial biometric measurements, the basal area for each treatment was calculated using the formula: $b a=\pi d^{2} / 4$, where ab represents the basal area and $d$ is the tree DBH. Subsequently, the basal area was extrapolated to a per hectare basis assuming a population of 1600 trees (spacing $2.5 \mathrm{~m} \times 2.5 \mathrm{~m}$ ). Volume calculations were based on Equation 1:

$V=\frac{3}{4} b a \times h$

where: $\mathrm{V}$ is volume, ba is basal area, and $\mathrm{h}$ is tree height. 
Calculations of volume per treatment were also extrapolated to a per hectare basis assuming a population of 1600 trees (spacing $2.5 \mathrm{~m} \times 2.5 \mathrm{~m}$ ). Needle sampling was initiated in August 2012 and was repeated annually through 2014. Approximately $100 \mathrm{~g}$ of needle fascicles (most recently-matured) were collected from the inferior whorl of the upper third of the crown (north face orientation of the plantations). These were weighed, oven dried $\left(60^{\circ} \mathrm{C}\right)$ for 24 hours, milled (Tecnal company - type Wiley mill), and packaged for analysis. Needle samples from all years were analyzed as described by Silva (1999). According to this methodology, $0.5 \mathrm{~g}$ of needle tissue initially received $4 \mathrm{ml}$ of nitric acid $\left(\mathrm{HNO}_{3}, 65 \%\right)$ and were allowed to stand at room temperature for 12 hours for determination of $\mathrm{P}, \mathrm{K}, \mathrm{Ca}, \mathrm{Mg}, \mathrm{Cu}, \mathrm{Fe}, \mathrm{Mn}$, and $\mathrm{Zn}$. The temperature was then raised to $120^{\circ} \mathrm{C}$, and $2 \mathrm{ml}$ of perchloric acid $\left(\mathrm{HClO}_{4}, 70 \%\right)$ was added before raising the temperature to $180^{\circ} \mathrm{C}$. Cooled extracts were placed in $25 \mathrm{ml}$ volumetric flasks and brought to volume with deionized water. This diluted material was analyzed by Atomic Absorption Spectrophotometry (Varian - AA240 FS). For N and S determinations, a Perkin-Elmer CHNS/OPEZ 400 Series Element Analyzer was used. For the micronutrient B, solubilization was performed by the dry route; the reaction of boric acid with the azomethine- $\mathrm{H}$ reagent was colorimetrically analyzed (yellow intensity) using an UV-VIS spectrometer (Shimadzu - UV- VIS Mini - 1240).

\section{Statistical analysis and graphics}

Statistical analysis of the data was done considering a randomized block design with five replicates. Data were subjected to analysis of variance; when significant $(p<0.05)$, regression analysis was performed utilizing SAEG 9.1 - System for Statistical Analyzes (Sistema para Análises Estatísticas, 2007). Data were also analyzed by the Pearson's correlation, which is a measure of the linear correlation between two variables $X$ and $Y$ (Kent State University Libraries, 2019). Principal components analysis (PCA) was done for each year using the program R, which is a free software environment for statistical computing and graphics (R Development Core Team, 2017). PCA is a multivariate statistical analysis technique that linearly transforms an original set of variables (initially correlated with each other) into a substantially smaller set of uncorrelated variables that contain most of the original set information (Anderson, 2003). SigmaPlot 12.0, a graphing and statistical analysis software (Systat Software, San Jose, CA), was used to create the artwork.

\section{RESULTS AND DISCUSSION}

\section{Plant growth and elemental composition of needles}

Compost application enhanced $P$. taeda growth in terms of increased height, $\mathrm{DBH}$, basal area, and trunk volume (Figure 1). The difference in evaluated growth parameters displayed increasing effects over time, especially in the last evaluation year. This implies a residual effect of compost application on tree growth. Volume and basal area were more reflective of this residual effect than height and diameter. This was particularly evident in 2014 where maximum growth was attained in the $45 \mathrm{Mg} \mathrm{ha}^{-1}$ compost treatment; in this case, height, diameter, basal area, and trunk volume were increased by $22,38,63$, and $64 \%$, respectively. 

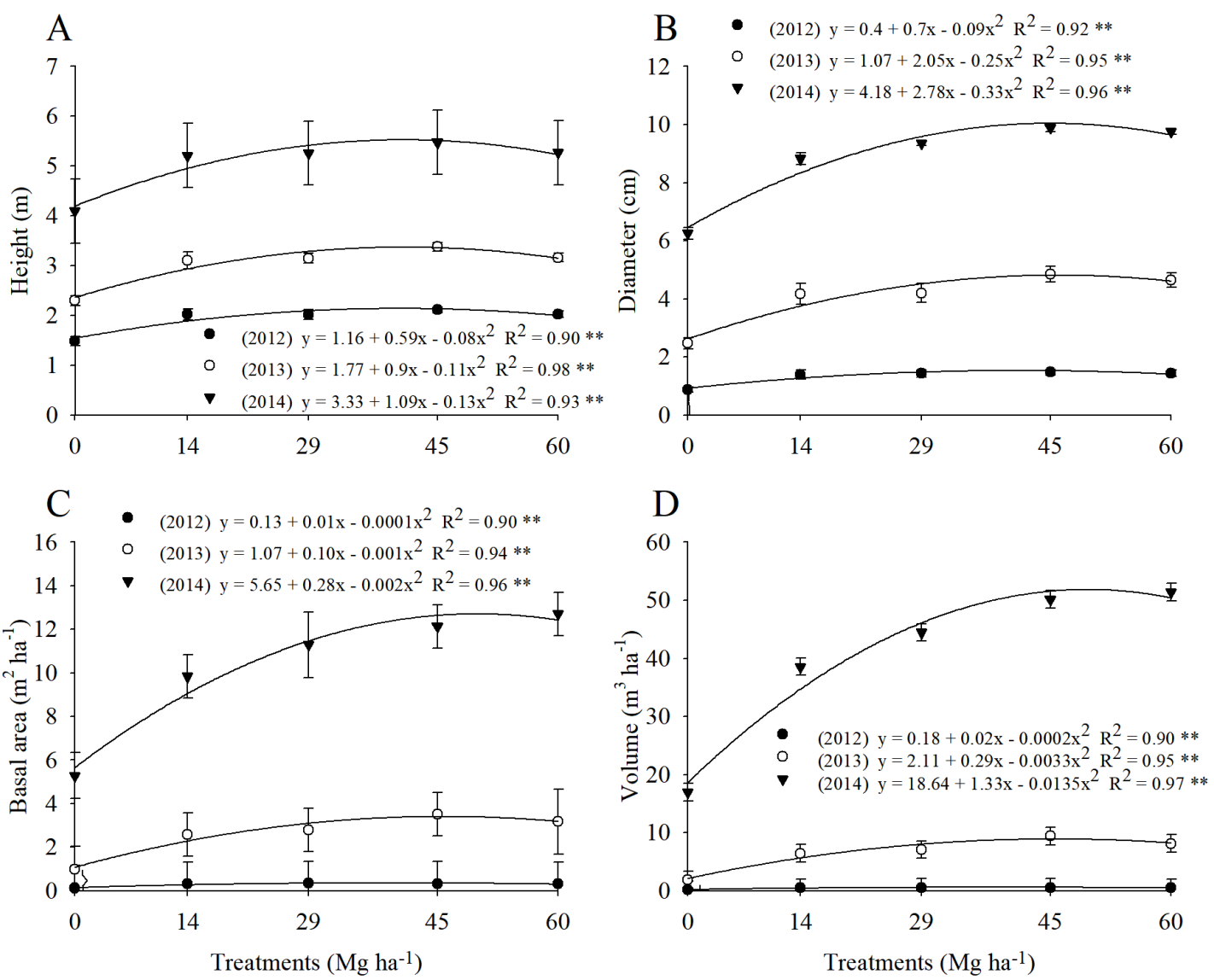

Figure1. Effect of increasing levels of compost (70\% cellulosic sludge and $30 \%$ boiler ash) on the biometric parameters height (A), diameter (B), basal area (C), and volume (D) of Pinus taeda trees in Piraí do Sul, Paraná, Brazil, from 2012 to 2014. ns = not significant; ** = Significant at 1\%. Bars denotes standard deviation.

The prompt and large responses to compost application in our study is likely related to soil fertility, favorable weather, and pine growth potential (i.e., soil was inherently poor and nutrient depleted from two previous pine harvest cycles with no nutrient replacement; no growth limiting weather; and high genetic growth potential of $P$. taeda). Since soil in the experimental area is sandy, residue application may have also favored the retention of soil water (Eden et al., 2017). In addition, the application of organic residues to soil tends to favor biological activity (Tian et al., 2015). After 7 years of cellulose paper waste applications, Rodrigues et al. (2005) also reported large enhancements in pine growth, with maximum response occurring at a rate of $74 \mathrm{Mg} \mathrm{ha}^{-1}$. In addition, Faustino et al. (2013) and Moro et al. (2014) reported positive growth responses to commercial fertilizer application despite the low nutritional requirements of pine. Other researchers reported that application of pulp and paper mill sludge increased conifer diameter and height (Ortega Rodriguez et al., 2018).

Extrapolations indicate that the maximum values for basal area and trunk volume were attained at 40, 45, and $50 \mathrm{Mg} \mathrm{ha}^{-1}$ of compost for 2012, 2013, and 2014 (Figure 1), respectively. This rate change over time may be related to an accumulation of compost residual effects. Similarly, Wang et al. (2013) reported that the application of biosolids in pine plantations resulted in a $36 \%$ increase in tree trunk volume. In contrast to our results, Jacobson (2003) found that ash applications diminished growth in a temperate forest of low fertility. Similarly, Parn (2005) observed a decrease in P. sylvestris growth with a $5 \mathrm{Mg} \mathrm{ha}^{-1}$ application of wood ash.

Symptoms of nutritional deficiency did not occur in our treated experimental plots. Although the control treatment exhibited slight indications of deficiency, these were not as pronounced as those seen in adjacent non-experimental areas. Possibly, the control received 
some nutrient uptake via root incursion into near-by composted plots. Thus, our observed responses may underestimate actual responses on a larger scale. Nevertheless, this did not prevent large increases in $P$. taeda growth due to compost application.

The addition of compost promoted alterations in the concentration of macronutrients in P. taeda needles. In 2012 and 2014, N, P, and K concentrations were altered, while Ca, Mg, and $S$ were only altered in 2014 (Figure 2). In 2012, an inverse relationship between N and P and applied compost rate was observed. The decrease was particularly low for $\mathrm{N}$.
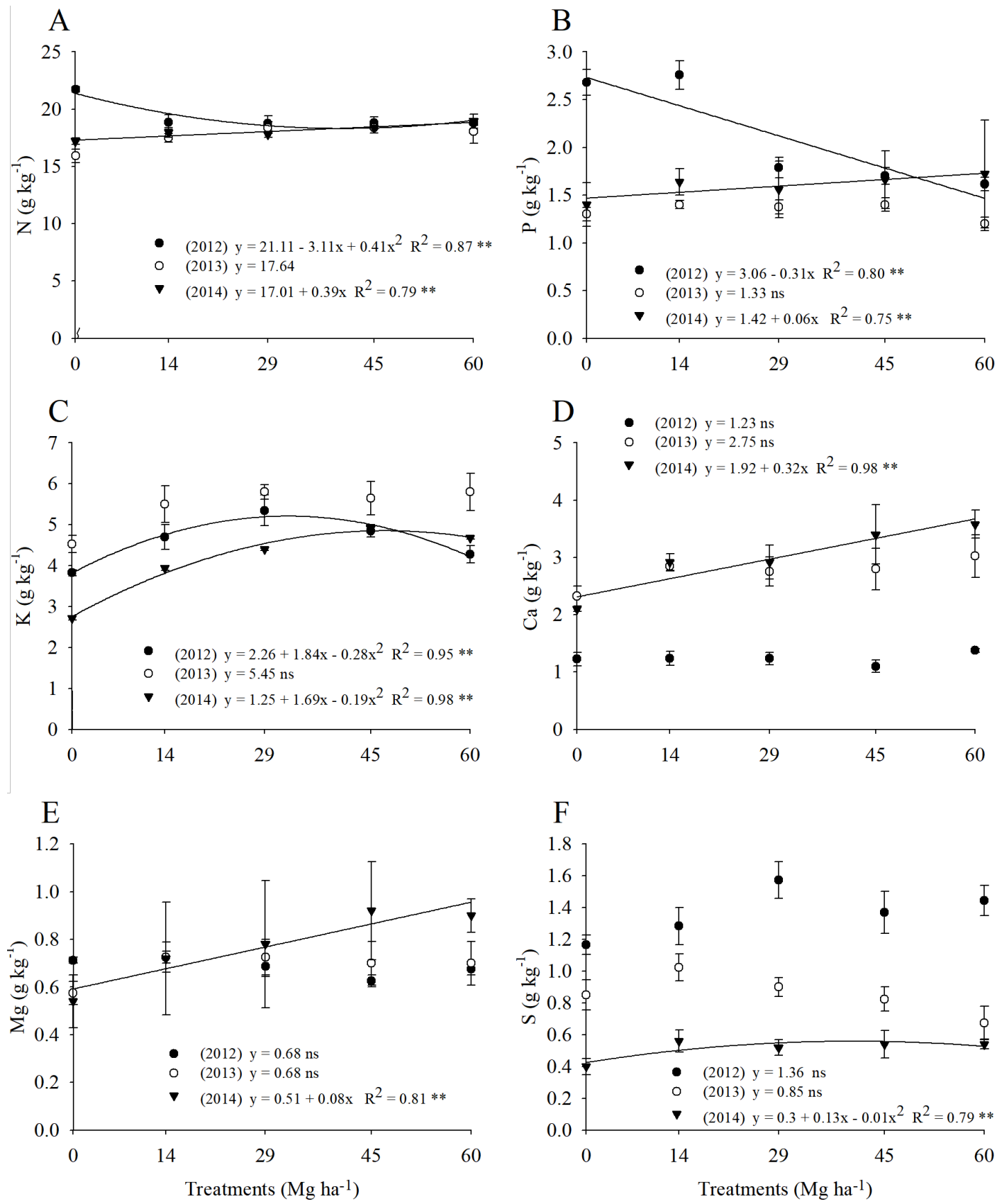

Figure2.Effect of increasing levels of compost(70\% cellulosic sludge and 30\% boiler ash) on the concentration of nitrogen (A), phosphorus (B), potassium (C), calcium (D), magnesium (E) and sulfur (F) in Pinus taeda needles, Piraí do Sul, Paraná, Brazil from 2012 to 2014. ns = not significant; ** $=$ Significant at $1 \%$. Bars denotes standard deviation.

The concentrations of needle $\mathrm{N}$ and $\mathrm{P}$ in the control (Figure 2) for the three years of collection are above the limits considered critical for $P$. taeda (12 and $1.2 \mathrm{mg} \mathrm{kg}^{-1}$, respectively). The values of $\mathrm{N}$ and $\mathrm{P}$ (Figure 2 ) were unexpected given the low available $\mathrm{P}$ and organic matter 
in this soil. Litter additions from previous tree rotations may have contributed to the availability of these nutrients. However, $\mathrm{K}, \mathrm{Ca}, \mathrm{Mg}$, and $\mathrm{S}$ (Figure 2) were below or very close to critical levels (4, 1.5, 0.8 and $1.2 \mathrm{mg} \mathrm{kg}^{-1}$, respectively) as reported by Sypert (2006).

Although the decline of $\mathrm{P}$ was greater, the final value remained above $1.2 \mathrm{mg} \mathrm{kg}^{-1}$, which is the minimum required by Pinus. The decreases observed were unexpected and may be associated with the dilution effect generated by plant growth. However, the observed changes were probably not a threat to overall nutritional status. The increased K (from critical to slightly higher values) may reflect an improvement in nutritional status and subsequent growth. Although no change in macronutrients was observed in 2013, Ca values were much higher than in 2012, and S showed the opposite pattern at a lower intensity (Figure 2).

The quadratic increase for $\mathrm{N}, \mathrm{K}$, and $\mathrm{S}$ and a linear response for $\mathrm{P}, \mathrm{Ca}$, and $\mathrm{Mg}$ concentrations seen in needles for 2014 (Figure 2) suggests an intensification of the compost effect over time. Regardless of compost rate, a decrease in S and K concentrations (relative to 2013) indicate the possible onset of nutrient exhaustion or dilution. Previous work has shown that $\mathrm{K}$ is the element most frequently associated with concentration changes from application of various residues (Sikstrom et al., 2010; Rodrigues et al., 2005; Jacobson, 2003). Changes in $\mathrm{K}$ could be due to its high solubility and concentration in utilized residues (Dibdiakova et al., 2015). In addition, the very low availability of soil K likely contributes to changes observed in plant tissue. Similar incremental changes in $\mathrm{Ca}$ and $\mathrm{Mg}$ were observed by Rodrigues et al. (2005) in a nearby study area. We also found a positive correlation between N and K (Figure 1) which suggests these nutrients may have impacted tree growth, despite the absence of a response in leaf tissue.

In the first year of evaluation, needle concentrations of $\mathrm{Mn}\left(1225 \mathrm{mg} \mathrm{kg}^{-1}\right), \mathrm{Cu}\left(23.5 \mathrm{mg} \mathrm{kg}^{-1}\right)$,

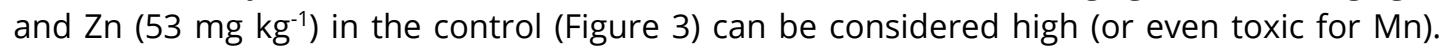
Needle concentrations of Fe $\left(69.5 \mathrm{mg} \mathrm{kg}^{-1}\right)$ and $\mathrm{B}\left(14 \mathrm{mg} \mathrm{kg}^{-1}\right)$ were considered to be normal and low, respectively. Among micronutrients, only Mn was influenced by compost application in the three years evaluated. 

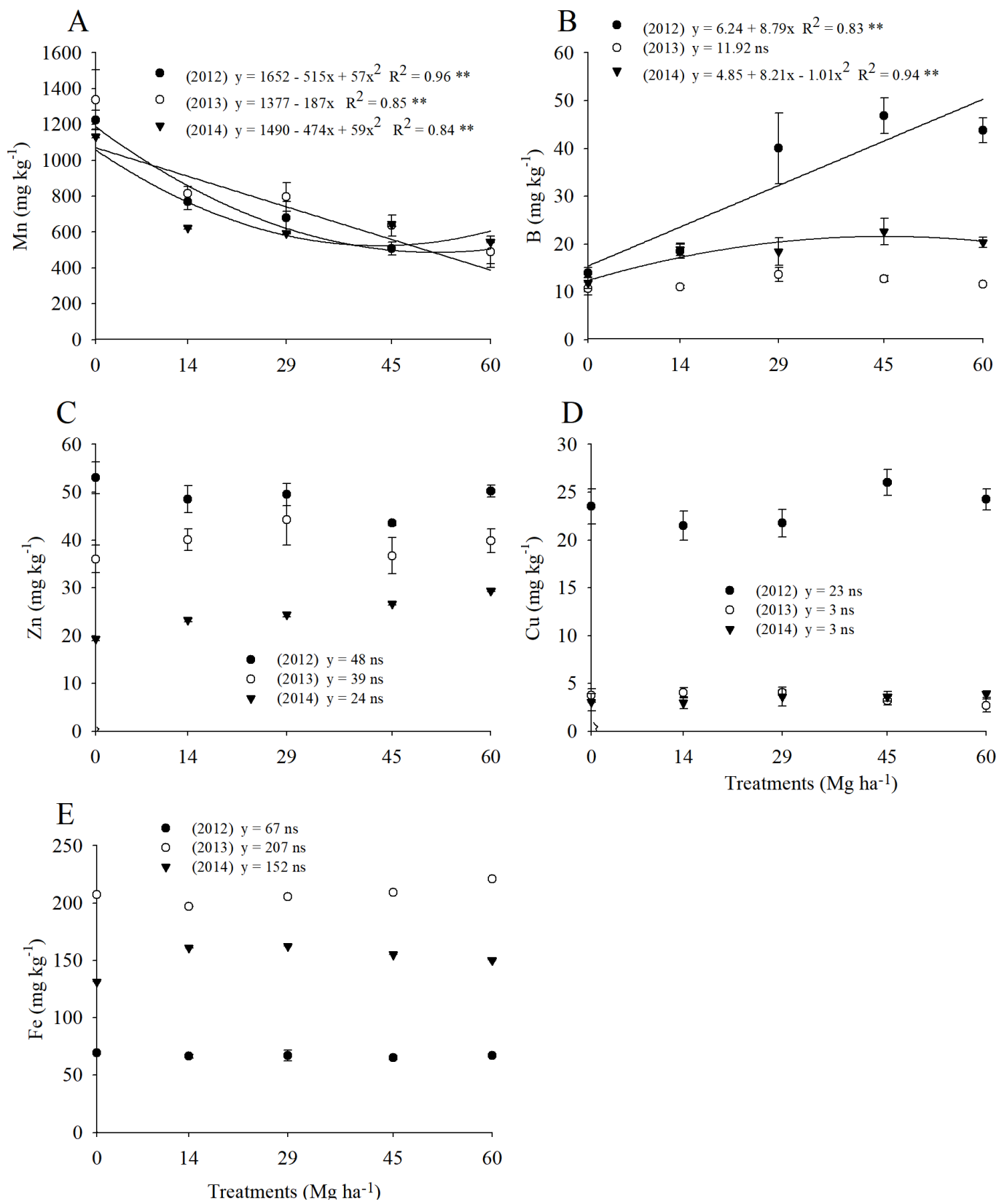

Figure3. Effect of increasing levels of compost (70\% cellulosic sludge and $30 \%$ boiler ash) on the concentration of manganese (A), boron (B), zinc (C), copper (D) and iron (E) in Pinus taeda needles, Piraí do Sul, Paraná, Brazil from 2012 to 2014. ns = not significant; ** = Significant at 1\%. Bars denotes standard deviation.

The high levels of $\mathrm{Zn}$ and $\mathrm{Cu}$ in needle tissue (Figure 3) was not expected since these micronutrients are generally low in sandy soils (as found at our study site). In contrast, low B was not surprising due to low reserves in sandstone soils observed in other areas of southern Brazil (Reissmann \& Wisniewski, 2005). Clearly, changes in Zn, Cu, B, and Fe concentrations were a function of sampling time, suggesting availability (or factors affecting availability) varied over time regardless of compost rate. This suggests changes in tissue micronutrient concentration occurred with plant growth.

The concentration of $\mathrm{Mn}$ exceeded $1000 \mathrm{mg} \mathrm{kg}^{-1}$ (Figure 3) in all years; this may be considered toxic according to Kavvadias \& Miller (1999). Our values were well above the highest values reported for Pinus spp. in the region; Schneider (2011) reported values of $166 \mathrm{mg} \mathrm{kg}^{-1}$ and $673 \mathrm{mg} \mathrm{kg}^{-1}$, respectively. Furthermore, our findings were above those observed in other regions where Chaves \& Corrêa (2005) reported values of $257 \mathrm{mg} \mathrm{kg}^{-1}$. 
Reissmann \& Wisniewski (2005) indicated that low growth sites had higher Mn (520 mg kg-1) compared to high growth sites $\left(267 \mathrm{mg} \mathrm{kg}^{-1}\right)$, resulting in low Fe/Mn ratios of 0.12 and 0.28 , respectively. Our study had a ratio close to or under 0.12 for the control and close to or above 0.28 for the compost treatments, which illustrates the importance of maintaining a balance between these nutrients.

High values of $\mathrm{Mn}$ in plants can be influenced by four factors: 1) high acidity; 2) anaerobic conditions (usually from waterlogging); 3) extraction capacity of the species; and 4) nutrient imbalance. Only the anaerobic condition did not apply to the experimental conditions of our study given the terrain texture and slope. The high level of $\mathrm{Mn}$ found in the Pinus needles (Figure 3 ) could be related to the low soil pH since it is well known that low pH favors soil $\mathrm{Mn}$ availability. However, no change in soil pH was observed when compost was applied (as shown below). Thus, decreased needle Mn concentration as a result of compost amendment may be related to improved nutritional status. Negative impacts of high $\mathrm{Mn}$ concentrations in plant tissue has been reported to affect enzyme activity, absorption, translocation, and other nutrients such as $\mathrm{Ca}, \mathrm{Mg}$, and $\mathrm{P}$ (Lei et al., 2007).

Corroborating our results, Schneider (2011) found diminished Mn in P. taeda needles after fertilization with and without liming. However, Sikstrom et al. (2010) found an increase of more than $100 \%$ when wood ash was used for $P$. sylvestris grown on peat soils in Sweden, but this pattern did not occur with fertilizer use. Thus, the influence of soil amendment on $\mathrm{Mn}$ nutritional status can vary among sites.

Correlation of nutrients in $P$. taeda needles with height and diameter are shown in Figure 4 and indicated change over time. A strong relationship between tree diameter and height was observed for all years. There were few correlations between plant height and diameter with nutrients in 2012; these correlations increased for all nutrients (except $\mathrm{Cu}$ ) by 2014. Apparently, the influence of compost amendments increased over time, according to observed growth patterns. The correlation between foliar $\mathrm{N}$ and growth showed negative or low positive values, suggesting a low importance for this macronutrient. Others macronutrients ( $\mathrm{P}, \mathrm{Ca}$, and $\mathrm{Mg}$ ) also had low correlation values for the last year. An inverse relationship between $\mathrm{Mn}$ and tree height and diameter was observed in all evaluations (Figure 4), indicating interference in plant development from toxicity or nutritional imbalance. After $\mathrm{Mn}, \mathrm{K}$ may have been an element that interfered (in degree and frequency) with plant growth, followed by $B$.

Based on growth correlations, we observed a direct correlation between $\mathrm{K} \times \mathrm{B}$, while an inverse correlation was seen for $\mathrm{Mn} \times \mathrm{K}$ and $\mathrm{Mn} \times \mathrm{B}$. The high correlations observed among macronutrients ( $\mathrm{Ca}, \mathrm{Mg}, \mathrm{K}, \mathrm{P}$, and $\mathrm{S}$ ) suggested an enhancement of plant nutrition by the presence of these elements in applied compost.

2012

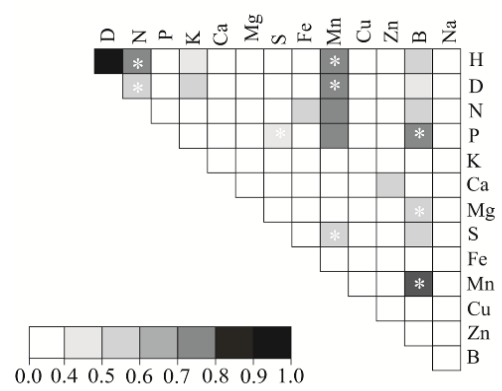

2013

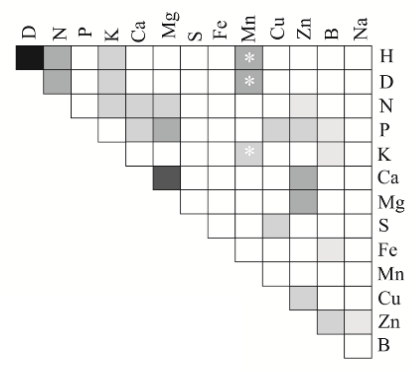

2014

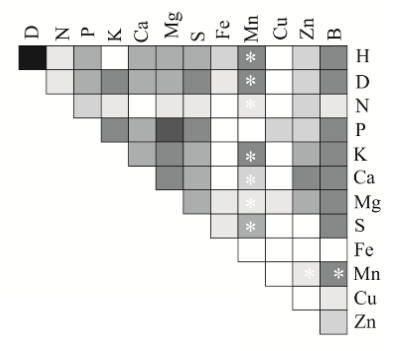

Figure 4. Correlation of nutrients in Pinus taeda needles with height $(H)$ and diameter (D) from 2012 to 2014 in Piraí do Sul, Paraná, Brazil. Blank spaces: not significant and * indicates a negative correlation.

Boron concentration increased (2012 and 2014) from a generally low level to a normal level (Figure 3 ) suggesting that this may be related to better P. taeda growth (Figure 1). 
Corroborating our results, Jacobson (2003) found elevation of B and K in P. sylvestris and Norway spruce (Picea abies (L.) Karst) needles after 3-5 years of wood ash application.

Among growth parameters, PCA analysis (Figure 5) also showed an inverse relationship for $\mathrm{Mn}$ and a direct relationship for $\mathrm{K}$ and $\mathrm{B}$ with tree growth. The influence of $\mathrm{Mn}$ strengthened with age and was segregated from others elements. Moreover, the effect of time on relationships among nutrients and their concentration in plant tissue was observed. In the last year, there was proximity of growth parameters with $\mathrm{B}, \mathrm{K}, \mathrm{Mg}, \mathrm{S}, \mathrm{Zn}, \mathrm{Ca}$, and Fe.

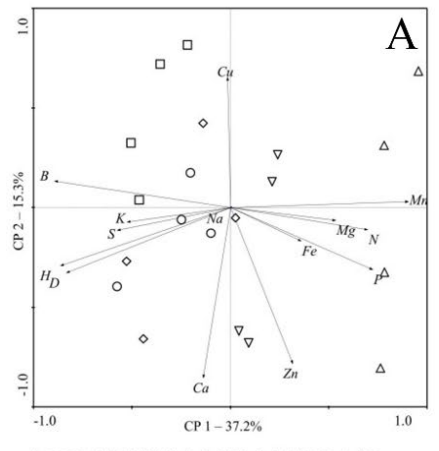

$\triangle 0 \mathrm{Mgha}^{-1} \nabla 14 \mathrm{Mg} \mathrm{ha}^{-1} \diamond 29 \mathrm{Mg} \mathrm{ha}^{-1} \square 45 \mathrm{Mgha}^{-1} \mathrm{O} 60 \mathrm{Mgha}$
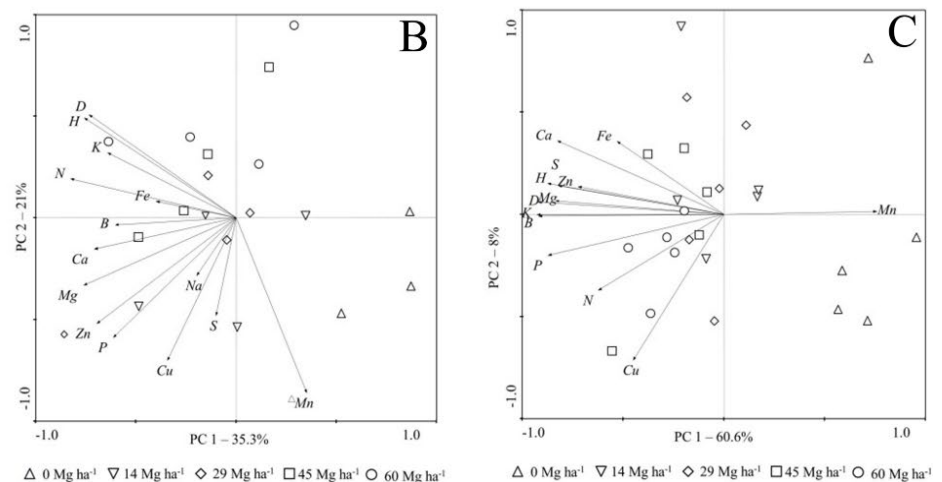

Figure 5. Analysis of the nutrient concentration principal components for needles in 2012 (A), 2013 (B) and 2014 (C).

\section{Soil chemical attributes under effect cellulosic residual}

Soil tests prior to imposing compost treatments in 2011 indicated low or very low soil fertility with an acidic $\mathrm{pH}$ and high $\mathrm{Al}^{3+}$ level. During soil collections in the three subsequent years $(2012,2013,2014)$, nutrient concentrations and pH generally remained low, but there were compost treatment effects on some variables related to soil fertility (Tables 3 and 4). Potassium was the most responsive nutrient for both soil depths $(0-10$ and $10-20 \mathrm{~cm})$ in 2012 and 2014. Copper showed a response in 2011 (top depth) and 2014 (both depths). For Al and C, changes occurred only in one depth in 2011 (bottom depth) and 2014 (top depth), respectively; Mn was affected at the second depth in 2013 and 2014 (Table 3 and 4).

Table 3. Effect of increasing compost rates (70\% cellulosic sludge and $30 \%$ boiler ash) on soil chemical characteristics at the $0-10 \mathrm{~cm}$ soil depth over 4 years of assessment. Piraí do Sul, Paraná State, Brazil.

\begin{tabular}{|c|c|c|c|c|c|c|c|c|}
\hline \multirow{2}{*}{ Parameter } & \multirow{2}{*}{ Year } & \multicolumn{5}{|c|}{ Treatment (Mg ha-1) } & \multirow{2}{*}{ Equation* } & \multirow{2}{*}{$\mathbf{R}^{2 * *}$} \\
\hline & & 0 & 14 & 25 & 49 & 60 & & \\
\hline \multirow{4}{*}{$\mathrm{pH}-\mathrm{CaCl}_{2}$} & 2011 & 3.90 & 3.97 & 3.91 & 3.86 & 4.02 & $y=3.93$ & ns \\
\hline & 2012 & 3.67 & 3.72 & 3.82 & 3.75 & 3.77 & $y=3.75$ & ns \\
\hline & 2013 & 3.70 & 3.62 & 3.62 & 3.67 & 3.67 & $y=3.66$ & ns \\
\hline & 2014 & 3.75 & 3.62 & 3.75 & 3.75 & 3.82 & $y=3.74$ & ns \\
\hline \multirow{4}{*}{$\mathrm{Al}^{3+}$} & 2011 & 0.63 & 0.59 & 0.56 & 0.57 & 0.44 & $y=0.56$ & ns \\
\hline & 2012 & 1.32 & 1.23 & 1.05 & 1.10 & 1.02 & $y=1.14$ & ns \\
\hline & 2013 & 1.42 & 1.45 & 1.35 & 1.37 & 1.37 & $y=1.39$ & ns \\
\hline & 2014 & 1.42 & 1.82 & 1.52 & 1.35 & 1.45 & $y=1.51$ & ns \\
\hline \multirow{4}{*}{$\mathrm{H}+\mathrm{Al}$} & 2011 & 5.07 & 4.64 & 4.83 & 4.80 & 4.43 & $y=4.75$ & ns \\
\hline & 2012 & 7.09 & 6.82 & 5.96 & 6.77 & 6.48 & $y=6.62$ & ns \\
\hline & 2013 & 6.92 & 7.60 & 7.00 & 6.52 & 7.25 & $y=7.06$ & ns \\
\hline & 2014 & 5.07 & 6.65 & 6.22 & 5.42 & 5.17 & $y=5.71$ & ns \\
\hline
\end{tabular}


Table 3. Continued...

\begin{tabular}{|c|c|c|c|c|c|c|c|c|}
\hline \multirow{2}{*}{ Parameter } & \multirow{2}{*}{ Year } & \multicolumn{5}{|c|}{ Treatment (Mg ha-1) } & \multirow{2}{*}{ Equation* } & \multirow{2}{*}{$\mathbf{R}^{2 * *}$} \\
\hline & & 0 & 14 & 25 & 49 & 60 & & \\
\hline \multirow{4}{*}{$\mathrm{C}$} & 2011 & 6.24 & 7.37 & 5.36 & 5.46 & 6.35 & $y=6.15$ & ns \\
\hline & 2012 & 9.97 & 10.57 & 9.95 & 12.12 & 9.77 & $y=10.48$ & ns \\
\hline & 2013 & 10.07 & 10.10 & 11.97 & 9.40 & 11.75 & $y=10.66$ & ns \\
\hline & 2014 & 17.65 & 20.60 & 18.62 & 20.60 & 13.77 & $y=17.59+0.24 x-0.004 x^{2}$ & $0.73 * *$ \\
\hline \multirow{4}{*}{$\mathrm{K}^{+}$} & 2011 & 0.02 & 0.03 & 0.02 & 0.02 & 0.02 & $y=0.02$ & ns \\
\hline & 2012 & 0.01 & 0.01 & 0.02 & 0.03 & 0.02 & $y=0.01+0.002 x$ & $0.83 * *$ \\
\hline & 2013 & 0.02 & 0.02 & 0.02 & 0.02 & 0.02 & $y=0.02$ & ns \\
\hline & 2014 & 0.02 & 0.03 & 0.03 & 0.04 & 0.02 & $y=0.02+0.0008 x-$ & $0.57 * \star$ \\
\hline \multirow{4}{*}{$\mathrm{Ca}^{2+}$} & 2011 & 0.13 & 0.16 & 0.06 & 0.04 & 0.08 & $y=0.09$ & ns \\
\hline & 2012 & 0.12 & 0.10 & 0.15 & 0.20 & 0.25 & $y=0.16$ & ns \\
\hline & 2013 & 0.10 & 0.10 & 0.10 & 0.15 & 0.25 & $y=0.14$ & ns \\
\hline & 2014 & 0.12 & 0.12 & 0.30 & 0.30 & 0.30 & $y=0.23$ & ns \\
\hline \multirow{4}{*}{$\mathrm{Mg}^{2+}$} & 2011 & 0.0 & 0.0 & 0.0 & 0.02 & 0.01 & $y=0.006$ & ns \\
\hline & 2012 & 0.17 & 0.20 & 0.25 & 0.22 & 0.20 & $y=0.21$ & ns \\
\hline & 2013 & 0.10 & 0.10 & 0.10 & 0.10 & 0.10 & $y=0.10$ & ns \\
\hline & 2014 & 0.10 & 0.10 & 0.10 & 0.10 & 0.10 & $y=0.10$ & ns \\
\hline \multirow{4}{*}{$P$} & 2011 & 1.88 & 2.10 & 2.96 & 3.33 & 2.78 & $y=2.61$ & ns \\
\hline & 2012 & 6.32 & 11.02 & 9.62 & 8.17 & 9.37 & $y=8.90$ & ns \\
\hline & 2013 & 4.45 & 6.30 & 5.27 & 5.37 & 5.07 & $y=5.29$ & ns \\
\hline & 2014 & 2.02 & 2.52 & 2.45 & 2.32 & 3.15 & $y=2.49$ & ns \\
\hline \multirow{4}{*}{$\mathrm{Cu}$} & 2011 & 0.31 & 0.40 & 0.48 & 0.50 & 0.53 & $y=0.34+0.003 x$ & $0.91 * *$ \\
\hline & 2012 & 0.65 & 0.68 & 0.60 & 0.50 & 0.50 & $y=0.58$ & ns \\
\hline & 2013 & 0.20 & 0.17 & 0.27 & 0.20 & 0.27 & $y=0.22$ & ns \\
\hline & 2014 & 1.10 & 0.87 & 0.90 & 1.05 & 0.65 & $y=1.05-0.0047 x$ & $0.42 *$ \\
\hline \multirow{4}{*}{$\mathrm{Mn}$} & 2011 & 1.10 & 1.15 & 1.08 & 1.45 & 1.56 & $y=1.27$ & ns \\
\hline & 2012 & 1.50 & 1.95 & 1.88 & 2.08 & 1.70 & $y=1.82$ & ns \\
\hline & 2013 & 1.00 & 1.12 & 1.15 & 0.63 & 0.80 & $y=0.94$ & ns \\
\hline & 2014 & 0.87 & 0.62 & 1.12 & 2.57 & 1.15 & $y=1.27$ & ns \\
\hline \multirow{4}{*}{$\mathrm{Fe}$} & 2011 & 62.33 & 92.50 & 84.00 & 83.66 & 102.00 & $y=84.90$ & ns \\
\hline & 2012 & 75.98 & 75.35 & 69.23 & 71.60 & 77.78 & $y=73.57$ & $0.96 *$ \\
\hline & 2013 & 52.00 & 54.62 & 55.02 & 54.95 & 56.52 & $y=54.62$ & ns \\
\hline & 2014 & 100.27 & 99.62 & 97.77 & 90.05 & 100.92 & $y=97.73$ & ns \\
\hline \multirow{4}{*}{$\mathrm{Zn}$} & 2011 & 0.16 & 0.21 & 0.33 & 0.18 & 0.23 & $y=0.22$ & ns \\
\hline & 2012 & 0.20 & 0.38 & 0.20 & 0.18 & 0.35 & $y=0.25$ & $0.55^{\star}$ \\
\hline & 2013 & 1.20 & 0.10 & 0.10 & 0.20 & 0.12 & $y=0.34$ & ns \\
\hline & 2014 & 3.12 & 3.27 & 0.60 & 1.22 & 2.75 & $y=2.19$ & ns \\
\hline
\end{tabular}

* Equation= When the $\mathrm{R}^{2}$ was not significant and generated an equation, the exposed value is the mean of the treatment. ${ }^{* *} R^{2}$ is the coefficient of determination. It varies between 0 and $100 \%$ indicating how much the model can explain the observed values. 
Table 4. Effect of increasing compost rates (70\% cellulosic sludge and 30\% boiler ash) on soil chemical characteristics at the $10-20 \mathrm{~cm}$ soil depth over 4 years of assessment. Piraí do Sul, Paraná State, Brazil.

\begin{tabular}{|c|c|c|c|c|c|c|c|c|}
\hline \multirow{2}{*}{ Parameter } & \multirow{2}{*}{ Year } & \multicolumn{5}{|c|}{ Treatment (Mg ha-1) } & \multirow{2}{*}{ Equation* } & \multirow{2}{*}{$\mathrm{R}^{2 * *}$} \\
\hline & & 0 & 14 & 25 & 49 & 60 & & \\
\hline \multirow{4}{*}{$\mathrm{pH}-\mathrm{CaCl}_{2}$} & 2011 & 4.06 & 4.06 & 4.03 & 4.03 & 4.11 & $y=4.06$ & ns \\
\hline & 2012 & 3.95 & 4.02 & 4.00 & 4.07 & 3.97 & $y=4.00$ & ns \\
\hline & 2013 & 3.95 & 3.87 & 3.85 & 3.92 & 3.87 & $y=3.89$ & ns \\
\hline & 2014 & 3.95 & 3.87 & 3.95 & 3.92 & 3.97 & $y=3.93$ & ns \\
\hline \multirow{4}{*}{$\mathrm{Al}^{3+}$} & 2011 & 0.43 & 0.41 & 0.38 & 0.35 & 0.30 & $y=0.44-0.002 x$ & $0.96 * *$ \\
\hline & 2012 & 0.80 & 0.72 & 0.77 & 0.65 & 0.67 & $y=0.72$ & ns \\
\hline & 2013 & 0.82 & 0.90 & 0.87 & 0.90 & 0.97 & $y=0.89$ & ns \\
\hline & 2014 & 0.95 & 1.10 & 1.02 & 0.97 & 0.95 & $y=1.00$ & ns \\
\hline \multirow{4}{*}{$\mathrm{H}+\mathrm{Al}$} & 2011 & 3.57 & 3.67 & 3.51 & 3.58 & 3.43 & $y=3.55$ & ns \\
\hline & 2012 & 4.11 & 3.72 & 4.10 & 3.71 & 3.92 & $y=3.91$ & ns \\
\hline & 2013 & 4.75 & 4.82 & 4.87 & 4.32 & 4.95 & $y=4.74$ & ns \\
\hline & 2014 & 3.85 & 4.37 & 4.30 & 3.67 & 3.70 & $y=3.98$ & ns \\
\hline \multirow{4}{*}{$\mathrm{C}$} & 2011 & 6.21 & 4.05 & 2.84 & 3.83 & 4.90 & $y=4.37$ & ns \\
\hline & 2012 & 5.42 & 5.65 & 6.50 & 5.30 & 6.07 & $y=5.79$ & ns \\
\hline & 2013 & 6.90 & 6.67 & 6.67 & 8.50 & 8.72 & $y=7.49$ & ns \\
\hline & 2014 & 13.10 & 10.90 & 14.40 & 13.47 & 11.87 & $y=12.75$ & ns \\
\hline \multirow{4}{*}{$\mathrm{K}^{+}$} & 2011 & 0.01 & 0.02 & 0.01 & 0.01 & 0.02 & $y=0.01$ & ns \\
\hline & 2012 & 0.01 & 0.01 & 0.01 & 0.02 & 0.01 & $y=0.008+0.0001 x$ & $0.67 * *$ \\
\hline & 2013 & 0.02 & 0.01 & 0.01 & 0.01 & 0.01 & $y=0.016$ & ns \\
\hline & 2014 & 0.02 & 0.02 & 0.02 & 0.02 & 0.01 & $y=0.02+0.0003 x-$ & $0.77 *$ \\
\hline \multirow{4}{*}{$\mathrm{Ca}^{2+}$} & 2011 & 0.11 & 0.06 & 0.03 & 0.03 & 0.03 & $y=0.05$ & ns \\
\hline & 2012 & 0.10 & 0.10 & 0.10 & 0.10 & 0.12 & $y=0.10$ & ns \\
\hline & 2013 & 0.10 & 0.10 & 0.10 & 0.10 & 0.12 & $y=0.10$ & ns \\
\hline & 2014 & 0.12 & 0.10 & 0.12 & 0.15 & 0.12 & $y=0.12$ & ns \\
\hline \multirow{4}{*}{$\mathrm{Mg}^{2+}$} & 2011 & 0.0 & 0.02 & 0.0 & 0.01 & 0.0 & $y=0.008$ & ns \\
\hline & 2012 & 0.17 & 0.15 & 0.20 & 0.17 & 0.17 & $y=0.17$ & ns \\
\hline & 2013 & 0.10 & 0.10 & 0.10 & 0.10 & 0.10 & $y=0.10$ & ns \\
\hline & 2014 & 0.10 & 0.10 & 0.10 & 0.10 & 0.10 & $y=0.10$ & ns \\
\hline \multirow{4}{*}{$P$} & 2011 & 0.20 & 2.88 & 0.54 & 0.28 & 0.66 & $y=0.91$ & ns \\
\hline & 2012 & 3.10 & 3.40 & 3.47 & 3.20 & 3.60 & $y=3.35$ & ns \\
\hline & 2013 & 2.27 & 2.70 & 2.35 & 3.0 & 2.90 & $y=2.64$ & ns \\
\hline & 2014 & 1.37 & 1.20 & 1.50 & 1.25 & 1.70 & $y=1.40$ & ns \\
\hline \multirow{4}{*}{$\mathrm{Cu}$} & 2011 & 0.43 & 0.43 & 0.53 & 0.43 & 0.36 & $y=0.44$ & ns \\
\hline & 2012 & 0.83 & 0.88 & 0.85 & 0.98 & 0.88 & $y=0.88$ & ns \\
\hline & 2013 & 0.10 & 0.07 & 0.10 & 0.12 & 0.07 & $y=0.095$ & ns \\
\hline & 2014 & 1.12 & 1.12 & 1.25 & 1.25 & 0.92 & $y=1.07+0.01 x-$ & $0.73 * *$ \\
\hline \multirow{4}{*}{$\mathrm{Mn}$} & 2011 & 0.96 & 1.03 & 0.90 & 1.40 & 1.86 & $y=1.23$ & ns \\
\hline & 2012 & 1.40 & 1.78 & 2.18 & 2.25 & 2.25 & $y=1.95$ & $0.82 *$ \\
\hline & 2013 & 1.40 & 0.57 & 1.22 & 0.40 & 1.40 & $y=1.33-0.04 x+$ & $0.37 *$ \\
\hline & 2014 & 0.82 & 0.65 & 1.17 & 0.85 & 0.90 & $y=0.88$ & ns \\
\hline \multirow{4}{*}{$\mathrm{Fe}$} & 2011 & 93.66 & 74.66 & 76.66 & 96.66 & 110.00 & $y=90.33$ & ns \\
\hline & 2012 & 70.98 & 66.38 & 69.93 & 77.03 & 84.23 & $y=72.06$ & $0.66 *$ \\
\hline & 2013 & 69.65 & 62.47 & 61.77 & 65.95 & 63.87 & $y=64.74$ & ns \\
\hline & 2014 & 88.80 & 91.57 & 93.65 & 85.92 & 84.67 & $y=88.92$ & ns \\
\hline \multirow{4}{*}{$\mathrm{Zn}$} & 2011 & 0.16 & 0.16 & 0.33 & 0.16 & 0.20 & $y=0.20$ & ns \\
\hline & 2012 & 0.15 & 0.18 & 0.18 & 0.10 & 0.10 & $y=0,15$ & ns \\
\hline & 2013 & 0.10 & 0.10 & 0.10 & 0.12 & 0.10 & $y=0.10$ & ns \\
\hline & 2014 & 1.92 & 2.72 & 0.60 & 0.52 & 2.80 & $y=1.71$ & ns \\
\hline
\end{tabular}

* Equation= When the $\mathrm{R}^{2}$ was not significant and generated an equation, the exposed value is the mean of the treatment. ** $R^{2}$ is the coefficient of determination. It varies between 0 and $100 \%$ indicating how much the model can explain the observed values.

Correlations of soil nutrients and $\mathrm{pH}$ with tree biometric parameters showed weaker relationship compared to foliar analysis and occurred only in 2011 and 2012 (Figure 6). This could be explained by the low impact of residue on evaluated soil properties which was 
counter to effects observed on tree growth. In 2012, availability of the soil macronutrients $\mathrm{K}$ and $\mathrm{Mg}$ in the $0-10 \mathrm{~cm}$ depth was related to tree height and diameter, confirming the particular importance of K. Also, there was a greater number of interactions in the $0-10 \mathrm{~cm}$ soil layer compared to the $10-20 \mathrm{~cm}$ layer. This suggested that the top layer could be the focus in soil evaluations of compost amendments applied to the soil surface. Correlations with height and diameter occurred with the nutrients Fe and Mn in 2011 and 2012.In general, there was no consistent pattern in soil $\mathrm{Mn}$ concentration as a function of compost rates over the years (Table 3 and 4).
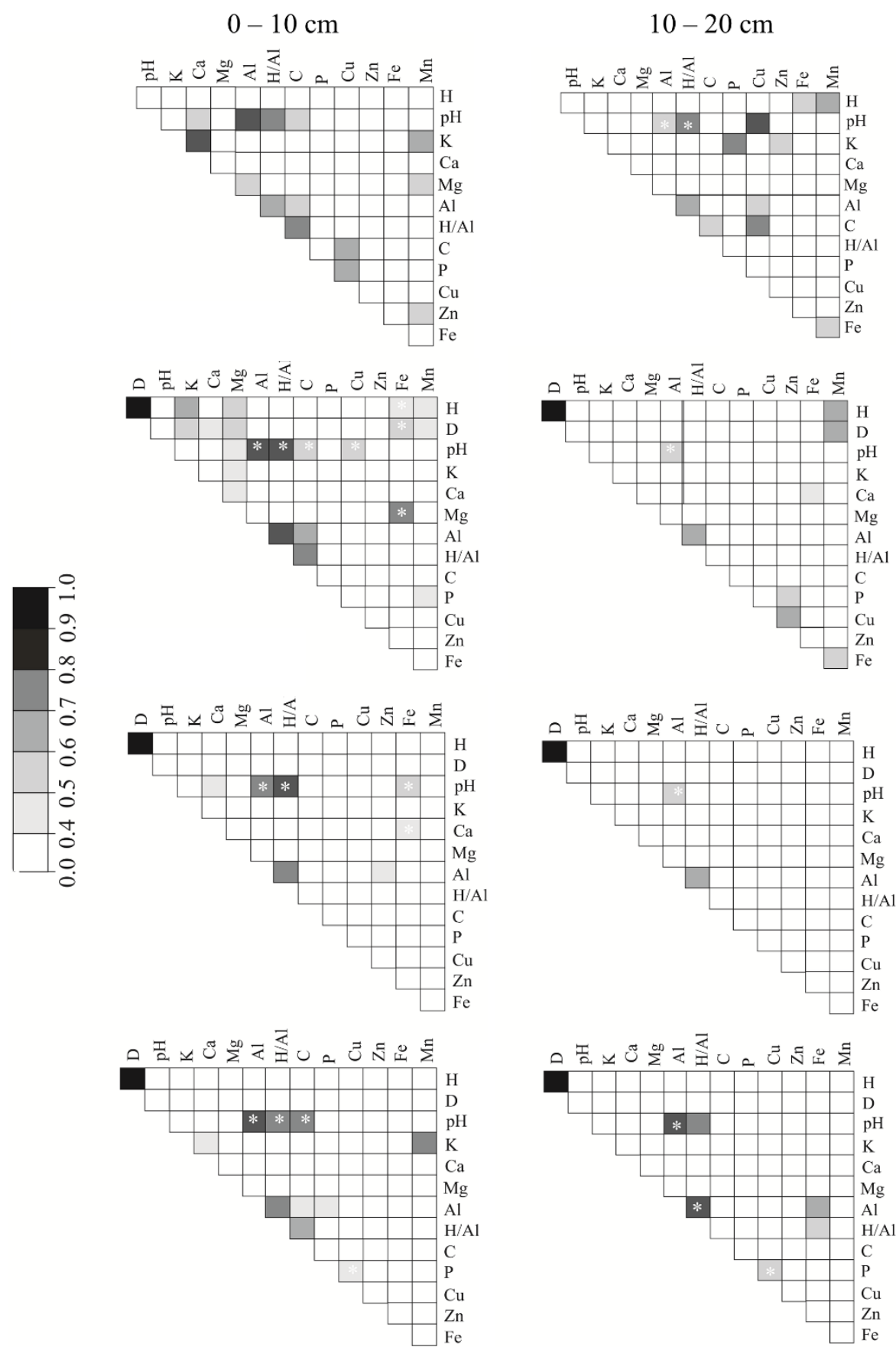

2014

Figure 6. Correlation between soil nutrients in the $0-10 \mathrm{~cm}$ and $10-20 \mathrm{~cm}$ soil depths with height $(\mathrm{H})$ and diameter (D) from 2011 to 2014 in Piraí do Sul, Paraná, Brazil. Blank spaces: not significant and *indicates a negative correlation. 
Soil chemical analysis showed few changes after compost application (Table 3 and 4), however, there was correlation with the growth of $P$. taeda (Figure 6), particularly in 2011 (first experiment year). Working with different rates of sewage sludge, Rigueiro-Rodríguez et al. (2010) observed a low impact on soil fertility factors with significant interference in $P$. radiata development. The genus Pinus has the ability to solubilize nutrients in the rhizosphere to capture nutrients required for proper development, even at low soil concentrations. Thus, it is possible that some nutrients were in forms that were not detectable by chemical methods utilized, suggesting that future studies may require supplementary soil analysis methods to address this issue.

\section{CONCLUSION}

The application of compost (cellulosic sludge - 70\% and boiler ash - 30\%) to the soil surface promoted $P$. taeda growth (height, DBH, basal area, and trunk volume) under a sandy soil with low natural fertility in subtropical Brazil. There was improvement in the nutritional status of $P$. taeda with increased needle $\mathrm{K}, \mathrm{P}, \mathrm{S}, \mathrm{Ca}, \mathrm{Mg}$ and $\mathrm{B}$, and decreased $\mathrm{Mn}$. The variation of $\mathrm{Mn}$ and $\mathrm{K}$ needle concentration play important roles on tree growth. Soil chemical analysis showed no constant or significant improvement in the evaluated parameters and provided little explanation for effects observed in the field. Overall, our findings suggest that the application of paper industry wastes to sites used to establish $P$. taeda plantations is an interesting alternative for recycling residues from pulp industry production. Besides providing a destination for these residues, applications will favor tree growth and contribute to more sustainable soil management.

\section{REFERENCES}

Alvares, C. A., Stape, J. L., Sentelhas, P. C., Gonçalves, J. L. M., \& Sparovek, G. (2013). Köppen's Climate Classification map for Brazil. Meteorologische. 22(6), 711-728.

Anderson, T. W. (2003). An introduction to multivariate statistical analysis (6th ed., 374 p.). New York: Wiley.

Associação Brasileira de Produtores de Florestas Plantadas - ABRAF. (2013). Anuário estatístico: ABRAF 2013 ano base 2012 (148 p.). Brasília: ABRAF.

Brasil. Ministério da Agricultura, Pecuária e Abastecimento. (2014). Manual de métodos analíticos oficiais para fertilizantes minerais, orgânicos, organominerais e corretivos (141p.). Brasília: MAPA.

Chaves, R. Q., \& Corrêa, G. F. (2005). Macronutrientes no sistema solo - Pinus caribaeaMorelet em plantios apresentando amarelecimento das acículas e morte das plantas. Revista Árvore, 29(5), 691-700. http://dx.doi.org/10.1590/S0100-67622005000500004.

Del Lungo, A., Ball, J., \& Carle, J. (2006). Global Planted Forests Thematic Study: Results and analysis (168 p.). Rome: FAO.

Dibdiakova, J., Wang, L., \& Li, H. (2015). Characterization of ashes from Pinus sy/vestris forest biomass. Energy Procedia, 75, 186-191. http://dx.doi.org/10.1016/j.egypro.2015.07.289.

Eden, M., Gerke, H. H., \& Houot, S. (2017). Organic waste recycling in agriculture and related effects on soil water retention and plant available water: A review. Agronomy for Sustainable Development, 37(2), 1-11.

Faustino, L. I., Bulfe, N. M., Pinazo, M. A., Monteoliva, S. E., \& Graciano, C. (2013). Dry weight partitioning and hydraulic traits in young Pinus taedatrees fertilized with nitrogen and phosphorus in a subtropical area. Tree Physiol, 33(3), 241-251.

Instituto Brasileiro de Árvores - IBA. (2017). Dados e Estatísticas (94 p.). Brasília: IBA.

Jacobson, S. (2003). Addition of stabilized wood ashes to Swedish coniferous stands on mineral soils: Effects on stem growth and needle nutrient concentrations. Silva Fennica, 37, 437-450.

Kavvadias, V. A., \& Miller, H. G. (1999). Manganese and calcium nutrition of Pinus sylvestris and Pinus nigra from two different origins. I. Manganese. Forestry, 72, 35-46.

Kent State University Libraries. (2019). SPSS tutorials: Pearson Correlation. Retrieved in 2019, May 28, from https://libguides.library.kent.edu/SPSS/PearsonCorr

Lei, Y., Korpelainen, H., \& Li, C. (2007). Physiological and biochemical responses to high Mn concentrations in two contrasting Populuscathayana populations. Chemosphere, 68, 686-694. 
Mandre, M., Parn, H., \& Ots, K. (2006). Short-term effects of wood ash on the soil and the lignin concentration and growth of Pinus sylvestris L. Forest Ecology and Management, 223, 349-357.

Morland, C., Schier, F., Janzen, N., \& Weimar, H. (2018). Supply and demand functions for global wood markets: specification and plausibility testing of econometric models within the global forest sector. Forest Policy and Economics, 92, 92-105.

Moro, L., Gatiboni, L. C., Simonete, M. A., Cassol, P. C., \& Chaves, D. M. (2014). Resposta de Pinus taeda com diferentes idades à adubação NPK no planalto Sul Catarinense. Revista Brasileira de Ciência do Solo, 38, 1181-1189.

Motta, A. C. V., Barbosa, J. Z., Consalter, R., \& Reismann, C. B. (2014). Nutrição e adubação da cultura do pinus. In R. M. Prado \& P. G. S. Wadt. Nutrição e adubação de espécies florestais e palmeiras (pp. 383-425). Jaboticabal: Gráfica e Editora Santa Terezinha.

Nolasco, A. M., Guerrini, I. A., \& Benedetti, V. (2005). Uso de resíduos urbanos e industriais como fonte de nutrientes e condicionadores de solos florestais. In J. L. M Gonçalves \& V. Benedetti. Nutrição e fertilização florestal (pp. 385-414). Piracicaba: IPEF.

Ortega Rodriguez, D. R., Andrade, G. C., Bellote, A. F. J., \& Tomazello-Filho, M. (2018). Effect of pulp and paper mill sludge on the development of 17-year-old loblolly pine (Pinus taeda L.) trees in Southern Brazil. Forest Ecology and Management, 422, 179-189. http://dx.doi.org/10.1016/j.foreco.2018.04.016.

Parn, H. (2005). Effect of wood ash application on radial and height growth of young Scots pines (Pinus sylvestris L.). Metsanduslikud Uurimused / Forestry Studies. 42, 48-57.

R Development Core Team (2017). R: A language and environment for statistical computing. Vienna, Austria: R Foundation for Statistical Computing. Retrieved in 2017, May 29, from http://www.R-project.org

Rabel, D. O., Motta, A. C. V., Barbosa, J. Z., Melo, V. F., \& Prior, S. A. (2018). Depth distribution of exchangeable aluminum in acid soils: A study from subtropical Brazil. Acta Scientiarum. Agronomy, 40, 01-10.

Reissmann, C. B., \& Wisniewski, C. (2005). Aspectos Nutricionais de Plantios de Pinus. In J.L.M Gonçalves \& V. Benedetti. Nutrição e fertilização florestal (pp. 420-421) Piracicaba: IPEF.

Rigueiro-Rodríguez, A., Castro, S., \& Mosquera-Losada, M. R. (2010). Effects of dose and period of sewage sludge application on soil, tree and pasture components in a Pinus radiata D. Don silvopastoral system. Agroforestry Systems, 79, 237-247.

Rodrigues, C. M., Belotte, A. F. J., Dedeck, R. A., \& Gomes, F. S. (2005). Produtividade do Pinus taeda L. provocada pela aplicação de resíduo celulósico. Boletim. Pesq.Florest, 51, 131-143.

Schneider, T. (2011). Crescimento e teores de B, Cu, Mn, Fe e Zn em Pinus taedaL., como resultado da adubação e calagem sob a técnica da omissão de nutrientes (50 p.). Curitiba: Universidade Federal do Paraná.

Sikstrom, U., Almqvist, C., \& Jansson, G. (2010). Growth of Pinus sylvestris after the application of wood ash or $\mathrm{P}$ and $\mathrm{K}$ fertilizer to a peatland in southern Sweden. Silva Fennica, 44, 411-425.

Silva, F. C. (1999). Manual de análises químicas de solos, plantas e fertilizantes (70 p.). Rio de Janeiro: Embrapa Solos.

Sistema para Análises Estatísticas - SAEG. (2007). Versão 9.1: Fundação Arthur Bernardes. Viçosa: UFV. Retrieved 2017, May 28, from http://arquivo.ufv.br/saeg/

Sypert, R. H. (2006). Diagnosis of Loblolly Pine (Pinus taeda L.) Nutrient deficiencies by foliar methods (115 p.). Blacksburg: Polytechnic Institute and State University.

Tian, W., Wang, L., Li, Y., Zhuang, K., Li, G., Zhang, J., Xiao, X., \& Xi, Y. (2015). Responses of microbial activity, abundance, and community in wheat soil after three years of heavy fertilization with manure-based compost and inorganic nitrogen. Agriculture, Ecosystems \& Environment, 213, 219-227.

Varnagiryte-Kabašinskiene, I., Stakenas, V., Mikšys, V., \& Kabašinskas, A. (2015). Vertical position of dry mass and elemental concentrations in Pinus sylvestris $L$. canopy under the different ash-nitrogen treatments. iForest, 8, 838-845.

Wang, H., Kimberley, M. O., \& Wilks, P. J. (2013). Economic analysis of a pine plantation receiving repeated applications of biosolids. PlosOne. 8(2):e57705.

Author's contributions: SASS: Investigation, Methodology, Writing - original draft; BASSACO: Formal Analysis, Writing - review \& editing; MOTTA: Supervision, Writing - original draft, Writing - review \& editing; MAEDA: Project administration, Investigation, Methodology, Supervision, Writing - original draft; BARBOSA: Methodology, Writing review \& editing; BOGNOLA: Project administration, Investigation, Methodology, Supervision, Writing - original draft; BOSCO: Project administration, Investigation, Methodology, Supervision, Writing - original draft; GOULARTE: Investigation, Methodology; PRIOR: Formal Analysis, Writing - review \& editing. 